\title{
HEPATITIS B VIRUS POSITIVE (HBSAG POSITIVE) AMONG THE BLOOD DONORS ATTENDED AT TRANSFUSION MEDICINE DEPARTMENT, DHAKA MEDICAL COLLEGE HOSPITAL, BANGLADESH: A ONE YEAR STUDY
}

\author{
KARIM S ${ }^{1}$, BEGUM HA ${ }^{2}$, BEGUM HA ${ }^{3}$, HOQUE E $^{4}$, HOQUE MM $^{5}$, ISLAM K ${ }^{6}$, ALAM MA ${ }^{7}$, SARKAR PK ${ }^{8}$
}

\begin{abstract}
Context: The possibility of hepatitis transmission through blood and blood products is very high and pretransfusion screening is mandatory by law in our country. The present study was carried out to find out the prevalence of Hepatitis B virus positive (HBsAg positive) among the blood donors attended the Department of Transfusion Medicine, Dhaka Medical College Hospital, Dhaka, in 2012.

Method: This cross sectional study was carried out in the Department of Transfusion Medicine, Dhaka Medical College Hospital, Dhaka, between January and December 2012. Total blood donors were 27,560. Blood donors of 18-60 years of both sexes were included in this study.

Results: Among 27,560 blood donors, relative blood donors were 21,081 (76.49\%) and voluntary blood donors were 6,479 (23.50\%). Among total blood donors male and female were 23,776 (86.26\%) and 3784 (13.73\%) respectively. 25,906 (93.99\%) were in 18-40 years age group and 1,654 (6\%) were in 41-60 years age group. A total of 453 were detected as $\mathrm{HBs} \mathrm{Ag}$ seropostive. Among them, relatives of the patients were 363 (1.7\%) and voluntary donors were 90 (1.4\%).
\end{abstract}

Key words: $H B s A g$, Blood donors, Seropositive.

J Dhaka Med Coll. 2013; 22(2) : 163-166.

\section{Introduction:}

The possibility of hepatitis transmission through blood and blood products were known since $1950 .{ }^{1-4}$ Researches show as that world prevalence of HBsAg carriers is from $0.1 \%$ till $20 \%$ with high percentage in tropical countries. ${ }^{5,6}$ Hepatitis B virus (HBV) infection with its associated sequel is a disease of major public health importance, being the $10^{\text {th }}$ leading cause of death globally. ${ }^{7,8}$ Approximately $15-40 \%$ of infected patients will develop cirrhosis, liver failure or hepatocellular carcinoma (HCC). ${ }^{9,10}$ The first serological marker to appear in the blood is the HBV DNA, followed by HBsAg, the DNA polymerase and HBeAg. Thereafter, the antibodies to the hepatitis $\mathrm{B}$ antigens (HBcAb, HBeAb and HBsAb) can be detected. Screening of donated blood by enzyme-linked immunosorbent assay (ELISA) for HBsAg is the common method for detecting hepatitis B infection ${ }^{11}$ Screening of blood for the detection of this viral marker, however, does not rule out the risk of transmission of hepatitis B totally, because there is a phase

1. Dr. Shanaz Karim, Medical Officer, Dept. of Transfusion Medicine, Dhaka Medical College Hospital, Dhaka.

2. Prof. Hussne Ara Begum, Head, Dept. of Transfusion Medicine, Dhaka Medical College Hospital, Dhaka.

3. Dr. Hosne Ara Begum, Associate Professor, Dept. of Transfusion Medicine, Dhaka Medical College Hospital, Dhaka.

4. Dr. Ehteshamul Hoque, Associate Professor, Dept. of Oncology, Anwer Khan Modern Medical College Hospital, Dhaka.

5. Dr. Md. Mazharul Hoque, Assistant Professor, Dept. of Transfusion Medicine, Dhaka Medical College Hospital, Dhaka

6. Dr. Kashfia Islam, Assist Regitrar, Dept of Transfusion Medicine, Dept. of Transfusion Medicine, Dhaka Medical College Hospital, Dhaka.

7 Dr. Md. Ashraful Alam, Medical Officer, Dept. of Transfusion Medicine, Dhaka Medical College Hospital, Dhaka.

8. Dr. Prodip Kumar Sarkar, Medical Officer, Dept. of Medicine, Dhaka Medical College, Dhaka

Correspondence: Dr. Shanaz Karim, Medical Officer, Dept. of Transfusion Medicine, Dhaka Medical College Hospital, Dhaka. 
during which the HBsAg cannot be detected in the blood although hepatitis B infection is present. This phase is known as the window period'. It represents a carrier state of the disease. Findings indicate that testing done for HBsAg alone is not sufficient to eliminate HBV infection through blood transfusion. ${ }^{11-14}$ The present study was carried out to find out the prevalence of Hepatitis B virus positive (HBsAg positive) among the blood donors attended the Department of Transfusion Medicine, Dhaka Medical College Hospital, Dhaka, in 2012.

\section{Methods:}

This study was carried out on 27,560 blood donors in the Department of Transfusion Medicine, Dhaka Medical College Hospital, Dhaka, from $1^{\text {st }}$ January to $31^{\text {st }}$ December of 2012. Among the 27,560 blood donors 21,081 were relatives of the patients and remaining 6,479 were voluntary donors. The age distribution of donor was $18-60$ years. Blood donors were selected after proper history taking and physical examination of donor which includes pulse, blood pressure, weight and estimation of hemoglobin. Prepared questionnaire in mother tongue were used for selection of donor. Those who were illiterate were assisted by the donor registration staff. Consent obtained in writing form from the donor after explaining the procedure, potential adverse reactions as well as the tests carried out on the donated blood. Some donors were rejected by self exclusion during conversation. Finally reviewed donors' health condition and performing physical examination, estimation of hemoglobin with Scala matching method. After fulfilling the criteria of donor selection, with all aseptic precaution, $5 \mathrm{ml}$ of blood was collected in prelabeled tube. Centrifuged the blood and separated the serum from cell. Detection of HBsAg was done by Latex agglutination immuno-chromatographic test with the instruction of reagent manufacturer. The test was reconfirmed by using ELISA method. The results were analyzed by using SPSS version 13.0.

\section{Results:}

In this study among 27,560 blood donors, relative blood donors were $21,081(76.49 \%)$ and voluntary blood donors were 6,479 (23.50\%). Among total blood donors male and female were $23,776(86.26 \%)$ and $3784(13.73 \%)$ respectively. $25,906(93.99 \%)$ were in $18-40$ years age group and 1,654 (6\%) were in 41-60 years age group. A total of 453 were detected as HBsAg seropostive. Among them, relatives of the patients were $363(1.7 \%)$ and voluntary donors were $90(1.4 \%)$. The Results are shown in the following tables:

Table-I

Distribution of types of blood donors

\begin{tabular}{lccc}
\hline Types of donor & Number & $\begin{array}{c}\text { Percentage } \\
\%\end{array}$ & $\begin{array}{c}\text { P } \\
\text { Value }\end{array}$ \\
\hline Relative & 21081 & 76.49 & 0.001 \\
Voluntary & 6479 & 23.5 & \\
\hline
\end{tabular}

Table-II

Distribution of age of blood donors

\begin{tabular}{lccc}
\hline Age & Number & Percentage & $\mathrm{P}$ \\
& & $\%$ & Value \\
\hline $18-40$ years & 25906 & $93.99 \%$ & 0.001 \\
$41-60$ years & 1654 & $6 \%$ & \\
\hline
\end{tabular}

Table-III

Distribution of sex of blood donor

\begin{tabular}{lccc}
\hline Sex & Number & Percentage & P \\
& & $\%$ & Value \\
\hline Male & 23776 & $86.26 \%$ & 0.001 \\
Female & 3784 & $14 \%$ & \\
\hline
\end{tabular}

Table-IV

Frequency of HBsAg Sero positive among relative and voluntary donor.

\begin{tabular}{lccccc}
\hline HBsAg & \multicolumn{2}{c}{ Relative } & \multicolumn{2}{c}{ Voluntary } & P \\
& \multicolumn{2}{c}{$(\mathrm{n}=21081)$} & \multicolumn{2}{c}{$(\mathrm{n}=6479)$} & value \\
& No & $\%$ & No & $\%$ & \\
\hline Positive & 363 & 1.7 & 90 & 1.4 & 0.065 \\
Negative & 20718 & 98.3 & 6389 & 98.6 & \\
\hline
\end{tabular}

Discussion:

The prevalence of HBsAg positive among healthy donor is apparently high and hepatitis infected blood donors may not be aware of their 
condition and therefore, have the chance to infect the patient. ${ }^{12}$ In this study among 27,560 blood donors, relatives of the patients were $21,081(76.49 \%)$ and voluntary blood donors were 6479 (23.50\%). The total number of HBsAg seropositive was found 453 (1.6436\%). Infection with HBV and HCV are worldwide significant problem in public health ${ }^{15-20}$. About 5\% (300 millions), of world population has chronic infection $\mathrm{HBV}$, which is major factor for developing of chronic liver cirrhosis and carcinoma hepatocelular ${ }^{21-25}$. The HBV prevalence among the blood donors of Kosovo is $4.2 \%$. Another study showed that among the blood donors in Kosovo, the prevalence of HBV was $12.05 \%$. With a population of more than 160 million, Bangladesh has a high HBsAg positively in adults (7.3-7.5\%). ${ }^{26,27}$

In this study, the prevalence of Hepatitis B infection obtained was $1.640 . \%$. This is lower compared to the $7.2 \%-7.5 \%$ HBsAg positivity in healthy adult population inBangladesh. ${ }^{26,27}$ There is decreasing trend of hepatitis B prevalence resulting from behavioral changes that have led to decrease $d$ transmission of infection. Due to public awareness of HBV hepatitis known infected person did not participate in the donation programmed. In. Bangladesh most HBV infection occurs in childhood and younger populations with a high rate of inter familial HBV Infection and the low rate of history of acute hepatitis. ${ }^{28} \mathrm{We}$ may conclude that after proper donor selection and donor blood screening for HBsAg will decrease the possibility of posttransfusion hepatitis significantly.

\section{Conclusion:}

There is a decreasing trend of posttransfusion hepatitis B prevalence resulting from donor selection and for blood screening and also vaccination. HBsAg seropositive donors should be informed about their disease, counseled and sent for confirmation to referral laboratory. After confirmation of the disease they should be referred to the hepatologist.

\section{References:}

1. Hillyer CD, Hillyer KL, Strobl FJ, Jefferies LC, Siberstein LE. eds. Handbook of transfusion medicine. $1^{\text {st }}$ ed. London: Academic Press; 2001.
2. Cerny A, Chisari FV: Pathogenesis of chronic hepatitis C: immunology features of hepatic injury and viral persistence. Hepatology 1999; 30: 595601.

3. Mahoney FJ. Update on Diagnosis, Management, and Prevention of Hepatitis B Virus Infection. Clin Microbiol Rev 1999, 12(2): 351-66.

4. Harmening DM. Modern blood banking and transfusion practices. $5^{\text {th }}$ ed. Philadelphia: FA Davis Company; 2005.

5. Friis RH, Sellers TA. Epidemiology for public health practice. $4^{\text {th }}$ ed. London: Jones and Bartlett Publishers; 2009.

6. Kyi KP, Aye M, Oo KM, Htun Moh, Oo SS, Lwin KO, Win KM: Prevalence of Hepatitis C in Healthy Population and Patients with Liver Ailments in Myanmar. Regional Health Forum WHO South-East Asia Region 2002; 6(1): .

7. Alao OO, Okwori OO, Egwu C, Audu F. Seroprevalence of Hepatitis B surface antigen among prospective Blood donor in an Urban Area of Benue state. Internet $J$ Hematol 2009; 5(2):

8. Lavanchy D. Hepatits B virus epidemiology, disease burden, treatment and current and emerging prevention and control measures. $J$ Viral Hepatol 2004; 11(2): 97-107.

9. Lok AS. Chronic hepatitis B. New Engl J Med 2002, 346: 1682-3.

10. Rob H. Hepatitis B. [Available from: http:// www.bbc.co.uk/health/physical_ health/ conditions/hepatitisb1.shtml] 2009.

11. Kumar H, Gupta PK, Jaiprakash BrigM. The role of anti-HBc IgM in screening of blood donors. MJAFI 2007, 63: 350-2.

12. Geraldine K, Adel A, Intesar A, Jameel N, Said HA. Evidence of occult Hepatitis B Virus infection among Omani Blood Donors: A preliminary study. Med Princ Pract 15: 368-72.

13. Marusawa H, Osaki Y, Kimura T, Ito K, Yamashita $\mathrm{Y}$, Eguchi $\mathrm{T}$, et al. High prevalence of antihepatitis $\mathrm{B}$ virus serological markers in patients with hepatitis c virus related chronic liver disease in Japan. Gut 1999; 45(2): 284-8.

14. Panhotra BR, Bahrani A, Joshi CS, U1 Hassan Zahoor. Occult hepatitis B virus infection among anti $\mathrm{HB}_{\mathrm{c}}$ positive blood donors: Necessitates substitutionof screening by HBV NAT. $J$ Infect 2005; 51(3): 263.

15. Zaller N, Nelson KE, Aladashvili M, Badridze N, del Rio C, Tsertvadze T. Risk factors for Hepatitis $\mathrm{C}$ virus infection among blood donors in Georgia. Eur J Epidemiol, Netherlands 2004, 19(6): 547-53. 
16. Lauer GM, Walker BD. Hepatitis $\mathrm{C}$ virus infection. New Engl J Med 2001, 345(1): 45-52.

17. Nelson KE, Wiliams CM. Infectious disease epidemiology: theory and practice. $2^{\text {nd }}$ ed. London: Jones and Bartlett Publishers; 2007.

18. Kimka N, Kingsley LA, Sayah N, Rinaldo CR. Hepatitis $\mathrm{C}$ virus infection in a male homosexual cohort: risk factor analysis. Genitourin Med 1996, 72: 213-6.

19. Gordis L. Epidemiology. $3^{\text {rd }}$ ed. Philadelphia: Elsevier; 2004.

20. Lok ASF. Chronic hepatitis B. New Engl J Med 2002; 346: 1682-3.

21. Dienstag JL, Schiff ER, Wright TL, Perrillo RP, Hann H-WL, Goodman Z, et al. for the U.S. Lamivudine Investigator Group: Lamivudine as initial treatment for chronic hepatitis B in the United States. New England J Med 1999; 341(17): 1256-63.

22. Mailliard ME, Gollan JL. Suppressing hepatitis B without resistance - So far, so good. New Engl $J$ Med 2003, 348(9): 848-50.
23. Ramadani N. Karakteristikat epidemiologjike dhe serologjike të Hepatitit B në Kosovë. [Abstract in English]. [PhD thesis]. Kosovo: Universitety of Pristina; 1992.

24. Scotionitis I, Brass CA, Mallet PF. Hepatitis C: Diagnosis and Treatment. J Gen Intern Med 1995, 10: 273-282.

25. Craig S. Epidemiology of Hepatitis B. Pediatr Infect Dis J 1999, 12(5): 433-6.

26. Islam MN, Islam KMN, Islam N. Hepatitis B virus in Dhaka, Bangladesh. Bangladesh Med Res Counc Bull 1984; 10: 1-6.

27. Khan M, Ahmed N. Seroepidemiology of HBV and HCV in Bangladesh. Int Hepatol Commun 1996; 5: $27-9$.

28. Alam S, Ahmad N, Mustafa G, Alam K, Khan M. Characteristics of treatment naive chronic hepatitis B in Bangladesh: younger populations are more effected; HBeAg-negatives are more advanced. Saudi J Gastroenterol 2008; 14(1): 15-9. 